\title{
Pollen Parent Effect on Outcrossing Rate, Yield, and Fruit Characteristics of 'Floridian' and 'Mauritius' Lychee
}

\author{
R.A. Stern', S. Gazit', R. El-Batsri, and C. Degani \\ Institute of Horticulture, Agricultural Research Organization, The Volcani Center, \\ Bet Dagan, Israel \\ Additional index words. Litchi chinensis, phosphoglucose isomerase, isozyme analysis, pollenizer, inbreeding depression \\ Abstract. Fruits produced in two orchards, each consisting of adjacent blocks of 'Floridian' and 'Mauritius' lychee \\ ( Litchi chinensis Sonn.), were unequivocally identified as selfed or outcrossed by phosphoglucose isomerase (PGP; EC \\ 5.3.1.9) isozyme analysis. The average rate of hybrid production in each orchard was $69 \%$ and $87 \%$ for 'Floridian' \\ and $17 \%$ and $65 \%$ for 'Mauritius', respectively. The percentage of hybrids produced on trees adjacent to those of \\ the other cultivar was invariably significantly higher than that produced on the more distant trees. However a \\ significant correlation between hybrid percentage and proximity to the other cultivar, as well as between hybrid \\ percentage and yield, was found only for 'Floridian' in one of the orchards. A significant correlation was found \\ between pollen source and the weights of fruits and seeds in both cultivars. Fruits originating from cross-pollination \\ were heavier and contained heavier seeds than selfed fruits. The most pronounced effect of pollen parent on seed \\ weight was found in 'Floridian', which appears to exhibit inbreeding depression.
}

The lychee, which belongs to the Sapindaceae family, produces one of the world's finest fruits (Galan-Sauco and Menini, 1989). China is the largest producer of lychee, followed by India. The crop is also grown commercially on a small scale in other countries such as Australia, South Africa, Israel, and the United States (Florida and Hawaii) (Cavaletto, 1980; GalanSauco and Menini, 1989; Joubert, 1986; Knight, 1980).

The lychee produces three types of flowers that open in succession on the same panicle (Chandler, 1958; Galan-Sauco and Menini, 1989; Joubert, 1986; Menzel, 1984; Scholefield, 1982). Type $I$ is defined as a functional male $\left(M_{2}\right)$, type II as a functional female, and type III as a functional male $\left(\mathrm{M}_{2}\right)$ with more hermaphroditic features than the type I flower. This pattern of flowering would be expected to promote cross-pollination and prevent self-pollination. However, male $\left(\mathbf{M}_{1}\right.$ and $\left.\mathbf{M}_{2}\right)$ and female flowering stages may overlap on the same tree or between trees of the same cultivar, thereby providing an opportunity for self-pollination (Joubert, 1986). Lychee is assumed to be self-compatible, since monocultivar lychee plantings are capable of bearing large crops, as found for 'Mauritius' in South Africa, 'Brewster' in Florida, and other cultivars in China (Campbell and Malo, 1968; Chandler, 1958; Joubert, 1986; McConchie and Batten, 1989; Menzel and Simpson, 1990; Popenoe, 1927).

To date, no studies have been made in lychee to examine the advantages, if any, of cross-pollination for fruit set; such advantages have been shown to exist in other fruit trees (Bergh, 1968; Degani et al., 1990; Gazit and Gafni, 1986; Sedgley and Griffin, 1989; Stephenson, 1981).

Until recently, only two commercial lychee cultivars were grown in Israel: 'Mauritius', introduced from South Africa, and

Received for publication 26 Feb. 1992. Accepted for publication 6 July 1992. Contribution from the Agricultural Research Organization, The Volcani Center P.O.B. 6, Bet Dagan, Israel, no. 3474-E, 1992 series. We thank H. Voet for her valuable help in the statistical analysis. The cost of publishing this paper was defrayed in part by the payment of page charges. Under postal regulations, this paper therefore must be hereby marked advertisement solely to indicate this fact.

'Dept. of Horticulture, Faculty of Agriculture, The Hebrew Univ. of Jerusalem, Rehovot, Israel

${ }^{2}$ To whom reprint requests should be addressed.
'Floridian', introduced from the United States (probably a seedling of 'Brewster'). These cultivars are often planted in adjacent blocks. This practice enabled us to study the effect of crosspollination on hybrid percentage using isozymes to analyze parentage, as had been done previously for avocado ( Persea americana Mill.) (Degani and Gazit, 1984; Degani et al., 1989, 1990; Goldring et al., 1987; Torres and Bergh, 1978a, 1978b; Vrecenar-Gadus and Ellstrand, 1985), pecan [ Carya illinoinensis (Wangenh.) K. Koch] (Marquard, 1988), and other species (Chapparo et al., 1987; Parfitt et al., 1985; Shaw and Allard, 1982; Tanksley, 1984).

In the present study, isozyme analysis was used to study the effect of pollen parent proximity on outcrossing rate and yield in two adjacent lychee monocultivar blocks. Identifying the pollen donor also enabled us to determine the effect of the pollen parent on fruit characteristics.

\section{Materials and Methods}

Plant material. The study was carried out in two commercial lychee orchards located in the Lower Galilee, Israel. One is in Kefar Hitim and the other in Arbel. The trees were planted in 1979. The lychee orchard in Kefar Hitim consisted of 10 rows (6 m apart) of 28 trees each (also $6 \mathrm{~m}$ apart). At its western end, the first five trees in each row were 'Floridian', the other 23, 'Mauritius'. The lychee orchard in Arbel consisted of six rows (6 m apart) of 16 trees each (also $6 \mathrm{~m}$ apart) split into two equal blocks: a 'Floridian' block located on the western side with eight trees per row and a 'Mauritius' block on the eastern side also with eight trees per row. The timing of the various flowering stages was monitored every 2 days in both orchards. For each flowering stage, the start, peak, and termination of flowering were determined.

At the beginning of the commercial harvest, mature lychee fruits were sampled from trees at increasing distances from the other cultivar. In the adjoining row, fruit samples were taken from both sides of the trees, i.e., the side facing the other cultivar and the opposite one. In the other rows, fruit was sampled from all sides of the tree. In each row, 90 to 100 fruits

Abbreviation: PGI, phosphoglucose isomerase. 
were sampled in quadruplicate, with two trees (Kefar Hitim) and one tree (Arbel) serving as the replicates. A total of 1991 fruits were picked and stored at 4C. Fruit and seed weights were determined before isozyme analysis of the cotyledons.

Isozyme analysis. Isozymes of PGI were resolved by electrophoresis on a $9 \%$ starch (Sigma, St. Louis) gel. Seeds were removed from the mature fruits and a $2 \times 5 \times 5 \mathrm{~mm}$ cotyledon slice was crushed in 0.2-ml crushing buffer (Degani and Gazit, 1984). Extract was absorbed onto $4 \times 6 \mathrm{~mm}$ Whatmand $3-\mathrm{mm}$ paper wicks that were then inserted into the gels. Wicks dipped in a solution of bromophenol blue were also inserted to visualize the migration of the front. A discontinuous buffer system (Ashton) was used (Lundkvist, 1979). The gel buffer consisted of one part Buffer A $(0.19$ M boric acid +0.05 M lithium hydroxide, $\mathrm{pH} 8.1)$ to nine parts Buffer $\mathrm{B}(0.051 \mathrm{M}$ Tris +0.008 $\mathrm{M}$ citric acid, $\mathrm{pH}$ 8.1). Buffer A served as the electrode buffer. Electrophoresis was performed at $4 \mathrm{C}$. The gels were run at 25 milliamper (mA) for the first $30 \mathrm{~min}$, paper wicks were removed, and electrophoresis was continued at a constant current of $50 \mathrm{~mA}$ until the dye front had travelled 9 to $10 \mathrm{~cm}$ from the point of origin. Gels were sliced and the sections anodal to the origin were stained for PGI activity (Goldring et al., 1985).

\section{Results}

PGI. Two zones of enzyme activity were detected in the isozyme pattern of PGI for 'Mauritius', 'Floridian', and their open-pollinated progenies (Fig. 1). In the less anodal zone, a fast-migrating single band was observed for 'Mauritius', while analysis of 'Floridian' revealed a slower migrating single band. 'Mauritius' x 'Floridian' hybrids showed a triple-banded phenotype, combining both parental bands and an intermediate one, indicating the dimeric structure of the PGI enzyme. PGI analysis
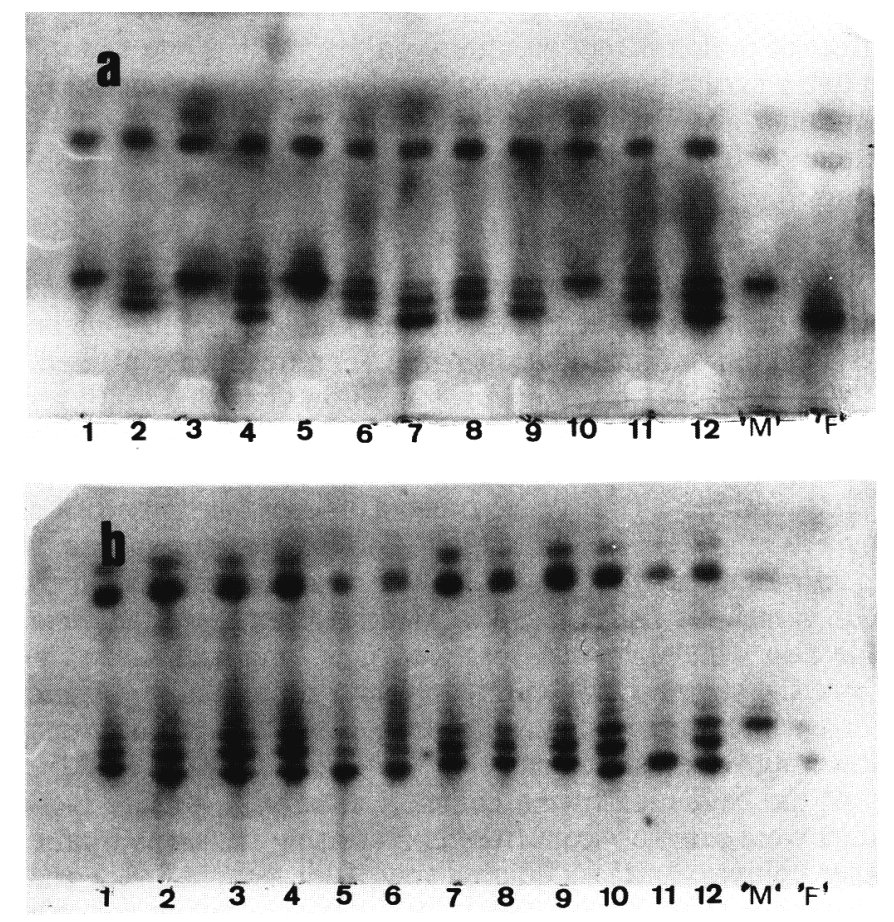

Fig. 1. Electrophoretic patterns of PGI isozymes in leaf extracts of 'Mauritius' ('M') and 'Floridian' (' $F$ ') cultivars and in embryo extracts of their progenies (1-12). (a) 'Mauritius' progeny (b) 'Floridian' progeny. The origin is at the bottom of each photo. Migration is toward the anode. therefore enabled unequivocal identification of each fruit's pollen parent.

Flowering phenology. In both orchards, some overlap occurred between female and male flowering, either within the same cultivar or between the two (Fig. 2), facilitating both crossand self-pollination.

Classification of fruits according to seed type. Fruits were classified into three groups according to seed weight and the presence of an embryo: 1) Embryo-containing seeds weighing $>1 \mathrm{~g}$, the most common type; 2) embryo-containing seeds weighing <1 g, the least common ones; and 3) shrivelled seeds, without discernible embryos (Table 1).

Rate of fruit production from self and cross-pollination. Parentage analyses could obviously only be carried out in embryocontaining fruits. In 'Floridian', most of the fruits produced were hybrids with 'Mauritius', particularly in the Arbel orchard (Table 2). With respect to production of selfed and cross-pollinated fruits in 'Mauritius', there was a marked difference between the two orchards. In Kefar Hitim about two-thirds the 'Mauritius' fruits were identified as hybrids with 'Floridian' vs. less than one-fifth in Arbel (Table 2).

The percentage of fruits with small seeds (weight $<1 \mathrm{~g}$ ) produced by self- or cross-pollination was examined. No 'Mauritius' fruits with small seeds were found at Kefar Hitim, but were found at Arbel in similar proportions in selfed and outcrossed fruits (Table 2). However, the percentage of 'Floridian' fruits with small seeds was 3.5 to 4.4 times higher in selfed than in outcrossed fruits in both orchards (Table 2). Thus, most 'Floridian' fruits with shrivelled seeds were apparently produced by self-pollination.

Effect of distance from the outcrossing pollen parent on hybrid percentage. Generally, in trees adjacent to those of the outcrossing pollen parent (pollenizer), no significant difference was found between hybrid percentages on the side facing the pollenizer and those on the opposite side (Table 3). However, for 'Mauritius' (Kefar Hitim), hybrid percentage was significantly higher on the side facing the pollenizer.

The percentage of hybrids produced on trees adjacent to those of the other cultivar [i.e., group A in Tables 4 ('Mauritius') and ('Floridian') 5] was invariably found to be significantly higher than the percentage of hybrids obtained from more distant trees (group B).

Within group B no decrease was observed in hybrid percentages with increasing distance from the pollenizer. In these trees, the difference in hybrid percentages was nonsignificant. This finding held true for the 'Mauritius' block at Kefar Hitim, where no significant difference in hybrid percentages was observed among trees located 12 to $132 \mathrm{~m}$ from the pollenizer (Table 4). In the Arbel orchard, hybrid percentages were relatively low for 'Mauritius' (Table 4) but very high for 'Floridian' (Table 5).

The effect of the out crossing pollen parent on yield. The yield per tree was not significantly affected by proximity to the pollenizer for 'Mauritius' in either orchard (although the yield in Kefar Hitim was nearly twice that in Arbel) and for 'Floridian' in Arbel (Tables 4 and 5). However, for 'Floridian' growing in Kefar Hitim, fruit yield of trees adjacent to the pollenizer was significantly higher (by 40\%) than that of the more distant trees.

The correlation between yield and hybrid percentage was low and nonsignificant for 'Floridian' in the Arbel orchard and for 'Mauritius' in either orchard. The correlation was high $(r=$ 0.63 ) and significant ( $P=0.05$ ) for 'Floridian' in Kefar Hitim.

The effect of pollen parent on fruit and seed weight. For both cultivars, a clear, consistent, and significant relation was found 


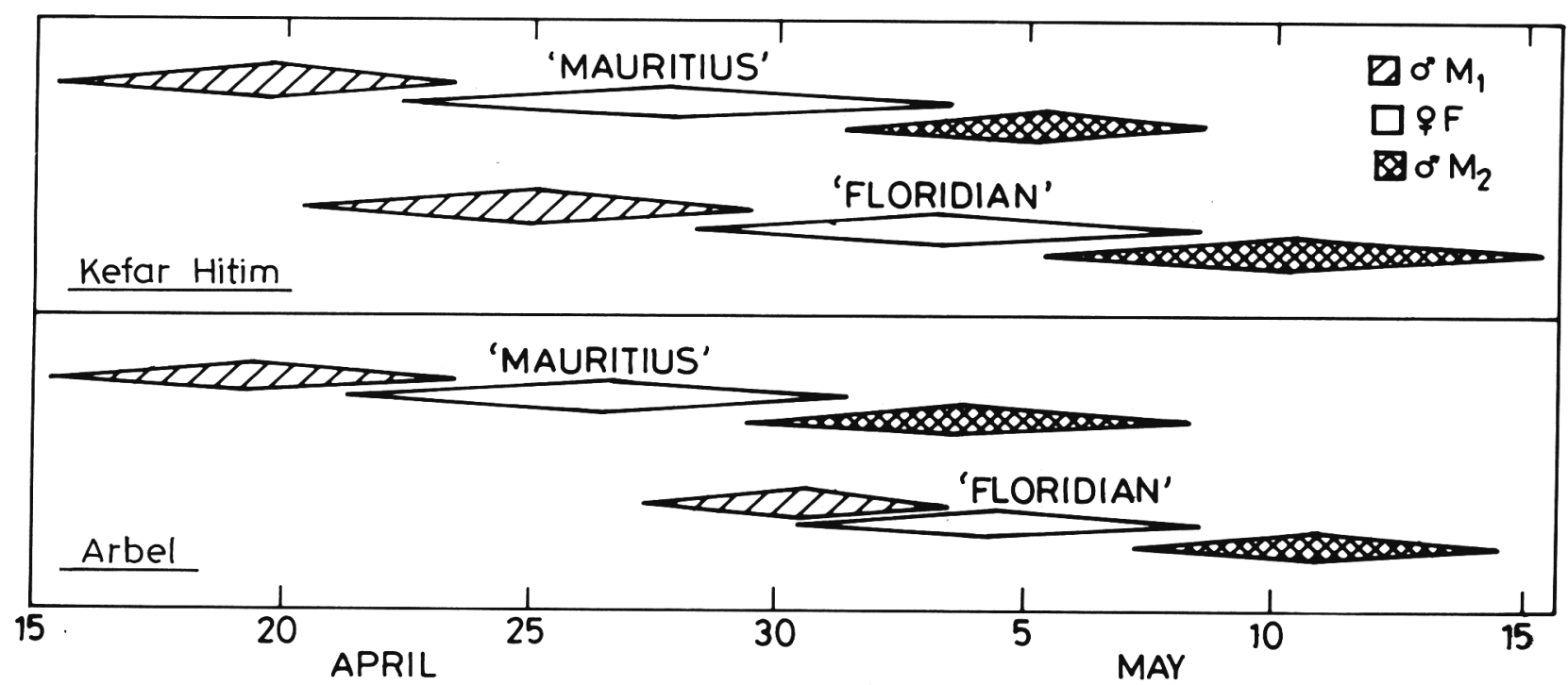

Fig. 2. Flowering phenology of 'Mauritius' and 'Floridian' in Kefar Hitim and Arbel orchards. Male flowering $\left(M_{1}\right)$; female flowering $(F)$; pseudohermaphroditic flowering (functionally male- $\mathrm{M}_{2}$ ). The peak of flowering is represented by the rhombus center, while the rhombus edges represent the start and termination of flowering.

Table 1. Proportion of 'Mauritius' and 'Floridian' lychee fruits with embryo-containing or shrivelled seeds.

\begin{tabular}{|c|c|c|c|c|c|}
\hline \multirow[b]{3}{*}{ Cultivar } & \multirow[b]{3}{*}{$\begin{array}{l}\text { Orchard } \\
\text { location }\end{array}$} & \multirow{3}{*}{$\begin{array}{c}\text { Fruits } \\
\text { sampled } \\
\text { (no.) }\end{array}$} & \multicolumn{3}{|c|}{ Fruits per seed class (\%) } \\
\hline & & & \multicolumn{2}{|c|}{$\begin{array}{l}\text { Embryo-containing } \\
\text { seeds }\end{array}$} & \multirow[b]{2}{*}{$\begin{array}{c}\text { Shrivelled } \\
\text { seeds }\end{array}$} \\
\hline & & & $\begin{array}{l}\text { Seed wt } \\
>1 \mathrm{~g}\end{array}$ & $\begin{array}{c}\text { Seed wt } \\
<1 \mathrm{~g}\end{array}$ & \\
\hline \multirow[t]{2}{*}{ Mauritius } & Kefar Hitim & 605 & 99 & 0 & 1 \\
\hline & Arbel & 449 & 85 & 7 & 8 \\
\hline \multirow[t]{2}{*}{ Floridian } & Kefar Hitim & 392 & 67 & 11 & 22 \\
\hline & Arbel & 465 & 95 & 2 & 3 \\
\hline
\end{tabular}

Table 2. Percentage of fruits with small seeds among fruits produced by self- or crosspollination of 'Mauritius' and 'Floridian'.

\begin{tabular}{|c|c|c|c|c|c|c|}
\hline \multirow[b]{2}{*}{ Cultivar } & \multirow{2}{*}{$\begin{array}{l}\text { Orchard } \\
\text { location }\end{array}$} & \multirow{2}{*}{$\begin{array}{l}\text { Embryo-containing } \\
\text { fruits (no.) }\end{array}$} & \multirow{2}{*}{$\begin{array}{l}\text { Cross-pollinated } \\
\text { fruits }(\%)\end{array}$} & \multicolumn{3}{|c|}{$\begin{array}{c}\text { Fruits with small seeds } \\
(\%)\end{array}$} \\
\hline & & & & Selfed & Crossed & Significance \\
\hline Mauritius & $\begin{array}{l}\text { Kefar Hitim } \\
\text { Arbel }\end{array}$ & $\begin{array}{l}579 \\
413\end{array}$ & $\begin{array}{l}65 \\
17\end{array}$ & $\begin{array}{l}0 \\
8\end{array}$ & $\begin{array}{l}0 \\
7\end{array}$ & --- \\
\hline Floridian & $\begin{array}{l}\text { Kefar Hitim } \\
\text { Arbel }\end{array}$ & $\begin{array}{l}306 \\
451 \\
\end{array}$ & $\begin{array}{l}69 \\
87 \\
\end{array}$ & $\begin{array}{r}31 \\
7\end{array}$ & $\begin{array}{l}7 \\
2 \\
\end{array}$ & $\begin{array}{c}* * * \\
*\end{array}$ \\
\hline
\end{tabular}

NS,*,***Nonsignificant or significant at $P=0.05$ or 0.001 , respectively, using $\chi^{2}$ test.

Table 3. Percentage of hybrid lychee fruits on facing and opposite side of trees adjacent to the pollenizer.

\begin{tabular}{llccccc}
\hline \hline & & \multicolumn{2}{c}{$\begin{array}{c}\text { Fruits sampled } \\
\text { (no.) }\end{array}$} & \multicolumn{2}{c}{$\begin{array}{c}\text { Hybrids } \\
(\%)\end{array}$} \\
\cline { 3 - 5 } \cline { 3 - 5 } Cultivar & Orchard & \multicolumn{4}{c}{ Side } & \\
\cline { 3 - 6 } location & Facing & Opposite & Facing & Opposite & Significance \\
\hline Mauritius & Kefar Hitim & 90 & 90 & 95 & 75 & $* *$ \\
& Arbel & 89 & 90 & 31 & 27 & NS \\
Floridian & Kefar Hitim & 94 & 100 & 68 & 67 & NS \\
& Arbel & 93 & 93 & 93 & 96 & NS \\
\hline
\end{tabular}

NS,**Nonsignificant or significant at $P=0.01$ using Duncan's multiple range test. 
Table 4. Percentage of fruits with shrivelled seeds, outcrossing rate, and yield in 'Mauritius' in response to distance from 'Floridian' lychee at two locations.

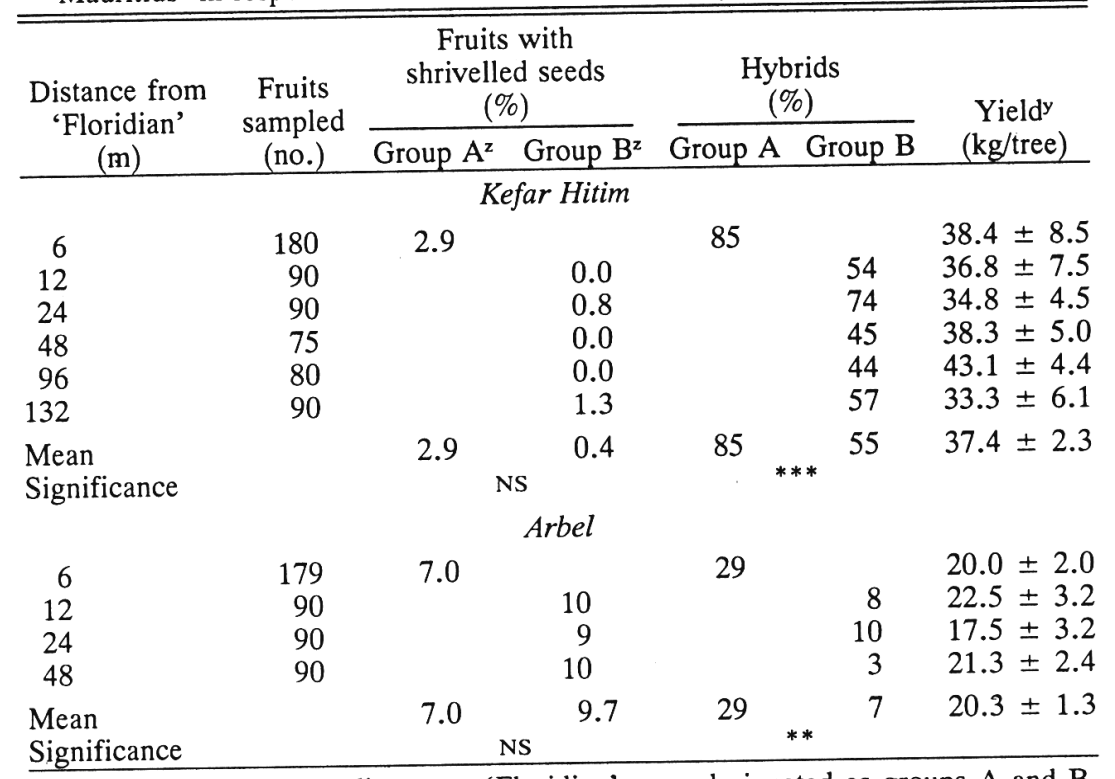

zTrees adjacent and nonadjacent to 'Floridian' were designated as groups A and B, respectively, for the statistical analyses.

yMean \pm SE.

NS,**,***Nonsignificant or significant at $P=0.01$ or 0.001 , respectively, using Duncan's multiple range test.

Table 5. Percentage of fruits with shrivelled seeds, outcrossing rate, and yield in 'Floridian' in response to distance from 'Mauritius' lychee at two locations.

\begin{tabular}{|c|c|c|c|c|c|c|}
\hline \multirow{2}{*}{$\begin{array}{c}\text { Distance from } \\
\text { 'Mauritius' } \\
(\mathrm{m}) \\
\end{array}$} & \multirow{2}{*}{$\begin{array}{c}\text { Fruits } \\
\text { sampled } \\
\text { (no.) }\end{array}$} & \multicolumn{2}{|c|}{$\begin{array}{c}\text { Fruits with } \\
\text { shrivelled seeds } \\
(\%)\end{array}$} & \multicolumn{2}{|c|}{$\begin{array}{c}\text { Hybrids } \\
(\%)\end{array}$} & \multirow{2}{*}{$\begin{array}{c}\text { Yieldy } \\
\text { (kg/tree) }\end{array}$} \\
\hline & & Group $A^{z}$ & Group $B^{2}$ & Group A & Group B & \\
\hline \multicolumn{7}{|c|}{ Kefar Hitim } \\
\hline $\begin{array}{r}6 \\
12 \\
24\end{array}$ & $\begin{array}{r}194 \\
99 \\
99\end{array}$ & 13 & $\begin{array}{l}31 \\
29\end{array}$ & 68 & $\begin{array}{l}41 \\
39\end{array}$ & $\begin{array}{l}22.5 \pm 3.0 \\
16.0 \pm 3.0 \\
16.0 \pm 3.8\end{array}$ \\
\hline $\begin{array}{l}\text { Mean } \\
\text { Significance }\end{array}$ & & 13 & 30 & 68 & 40 & $18.2 \pm 3.4$ \\
\hline \\
\hline $\begin{array}{r}6 \\
12 \\
24 \\
48\end{array}$ & $\begin{array}{r}186 \\
104 \\
91 \\
84\end{array}$ & 2 & $\begin{array}{l}7 \\
1 \\
1\end{array}$ & 95 & $\begin{array}{l}83 \\
82 \\
67\end{array}$ & $\begin{array}{l}22.5 \pm 3.2 \\
21.3 \pm 2.4 \\
23.8 \pm 2.3 \\
20.0 \pm 2.0\end{array}$ \\
\hline $\begin{array}{l}\text { Mean } \\
\text { Significance }\end{array}$ & & \multicolumn{2}{|c|}{ NS } & 95 & 77 & $21.8 \pm 2.0$ \\
\hline
\end{tabular}

${ }^{2}$ Trees adjacent and nonadjacent to 'Mauritius' were designated as groups A and B, respectively, for the statistical analyses.

yMean \pm SE.

NS,***Nonsignificant or significant at $P=0.001$ using Duncan's multiple range test.

between the pollen source and the weights of the fruits and seeds (Table 6). Fruits originating from cross-pollination were heavier (by $5 \%$ for 'Mauritius' and $6 \%$ for 'Floridian') and contained heavier seeds (by $10 \%$ for 'Mauritius' and $40 \%$ for 'Floridian') when compared to their selfed counterparts. Fruits with shrivelled seeds weighed significantly less than embryo containing fruits produced by self-pollination.
The seed weight percentage was highest in outcrossed fruits for 'Mauritius' and 'Floridian', lower in selfed fruits, and obviously lowest in fruits having shrivelled seeds. However, the difference between hybrid fruits and selfed fruits was only significant in 'Floridian'. In Arbel the commercial harvest of 'Floridian' was begun before fruits had reached maximum size. Therefore, these fruits had relatively low weights and high seed 
Table 6. Fruit and seed weight in three types of 'Mauritius' and 'Floridian' fruits in two orchard locations.

\begin{tabular}{|c|c|c|c|c|c|c|c|c|c|c|c|}
\hline \multirow[b]{2}{*}{ Fruit type } & \multicolumn{2}{|c|}{ Fruit (no.) } & \multicolumn{3}{|c|}{ Fruit $w^{2}(g)$} & \multicolumn{3}{|c|}{ Seed wt $(\mathrm{g})$} & \multicolumn{3}{|c|}{$\begin{array}{c}\text { Seed wt } \\
\text { percentage }\end{array}$} \\
\hline & K. Hitim & Arbel & K. Hitim & Arbel & Mean & K. Hitim & Arbel & Mean & K. Hitim & Arbel & Mean \\
\hline \multicolumn{12}{|c|}{ 'Mauritius' } \\
\hline Outcrossed & 387 & 71 & $18.5 \mathrm{a}$ & $18.0 \mathrm{a}$ & $18.3 \mathrm{a}$ & $3.8 \mathrm{a}$ & $2.6 \mathrm{a}$ & $3.2 \mathrm{a}$ & $20.9 \mathrm{a}$ & $14.4 \mathrm{a}$ & $17.7 \mathrm{a}$ \\
\hline Selfed & 211 & 341 & $17.3 \mathrm{~b}$ & & 17.5 & $3.5 \mathrm{~b}$ & 2. & & $20.4 \mathrm{a}$ & $13.4 \mathrm{a}$ & $16.9 \mathrm{a}$ \\
\hline Shrivelled seed & 7 & 37 & $17.0 \mathrm{ab}$ & $14.9 \mathrm{~b}$ & $16.0 \mathrm{c}$ & $0.9 \mathrm{c}$ & $0.4 \mathrm{~b}$ & $0.7 \mathrm{c}$ & $5.1 \mathrm{~b}$ & $3.0 \mathrm{~b}$ & $3.6 \mathrm{~b}$ \\
\hline \multicolumn{12}{|c|}{ 'Floridian' } \\
\hline Outcrossed & 211 & 395 & $19.1 \mathrm{a}$ & $11.8 \mathrm{a}$ & $15.5 \mathrm{a}$ & $3.0 \mathrm{a}$ & $2.7 \mathrm{a}$ & $2.8 \mathrm{a}$ & $15.3 \mathrm{a}$ & $23.0 \mathrm{a}$ & $19.2 \mathrm{a}$ \\
\hline Selfed & 95 & 57 & $18.1 \mathrm{~b}$ & $11.1 \mathrm{~b}$ & $14.6 \mathrm{~b}$ & $1.8 \mathrm{~b}$ & $2.2 \mathrm{~b}$ & $2.0 \mathrm{~b}$ & $9.8 \mathrm{~b}$ & $19.5 \mathrm{~b}$ & $14.7 \mathrm{~b}$ \\
\hline Shrivelled seed & 86 & 13 & $16.0 \mathrm{c}$ & $9.4 \mathrm{c}$ & $12.5 \mathrm{c}$ & $0.5 \mathrm{c}$ & $0.3 \mathrm{c}$ & $0.4 \mathrm{c}$ & $2.8 \mathrm{c}$ & $3.3 \mathrm{c}$ & $3.1 \mathrm{c}$ \\
\hline
\end{tabular}

${ }^{\mathrm{z}}$ Results within a column followed by different letters differ significantly by Tukey's test, $P=0.05$.

percentages as compared to 'Floridian' fruits harvested in Kefar Hitim (Table 6).

\section{Discussion}

Isozyme analysis of 'Mauritius' and 'Floridian' fruit embryos revealed significant fruit set from self-pollination in both cultivars (Tables 4 and 5). This result indicates that both cultivars are self-compatible.

Considerable differences in hybrid percentages were found between the two orchards for each cultivar. For 'Mauritius', a high percentage of hybrids was found in Kefar Hitim, while in Arbel the percentage was low (Table 4). This difference might be due to a difference in the availability of pollen during the female flowering stage of 'Mauritius' between the two orchards. 'Mauritius' female and male (both $\mathbf{M}_{1}$ and $\mathbf{M}_{2}$ ) flowering overlapped to a small extent in both orchards, while the degree of overlap between 'Mauritius' female flowering and 'Floridian' $M_{1}$ flowering was markedly higher in Kefar Hitim (Fig. 2). The percentage of hybrids in 'Floridian' was higher in Arbel than in Kefar Hitim (Table 5). This relationship is consistent with the observation that the 'Floridian' female flowering stage overlapped to a very small extent with its male flowering ( $\mathrm{M}$, and $\mathrm{M}_{2}$ ) stages in both orchards, while the overlap between the 'Floridian' female flowering stage and the 'Mauritius' $M_{2}$ flowering stage was almost complete in Arbel, and less so in Kefar Hitim (Fig. 2).

In both cultivars, the percentage of hybrids produced on trees adjacent to the cross-pollenizing cultivar was significantly higher than the percentage of hybrids on more distant trees (Tables 4 and 5). However, no significant difference in hybrid percentages was found among the more distant trees, ranging from 12 to $132 \mathrm{~m}$ from the pollenizer. Honeybees are the primary pollinators of lychee in Israel and other countries (Kadman and Slor, -1982; McGregor, 1976). The lack of a gradient in hybrid percentage with increasing distance from the pollen source suggests indirect pollination, i.e., via pollen transfer in the hive as has been suggested for some other fruits (DeGrandi-Hoffman et al., 1987; Free and Williams, 1972, 1976; Goldring et al., 1987; Kendall and Solomon, 1973). Direct cross-pollination is carried out by nectar-gathering bees wandering from the pollen-shedding $M_{1}$ or $M_{2}$ flowers of one lychee cultivar to the female flowers of another cultivar. This type of pollination probably only occurred to a significant degree on trees adjacent to the pollenizer trees, and in the case of 'Mauritius' in Kefar Hitim, it was restricted to the side facing the 'Floridian' trees (Table $3)$.

J. Amer. Soc. Hort. Sci. 118(1):109-114. 1993.
'Mauritius' yield was not found to correlate with either hybrid percentage or proximity to 'Floridian' trees (Table 4). This result indicates that cross-pollination by 'Floridian' holds no advantage over self-pollination in 'Mauritius'. The relatively low yield of 'Mauritius' in Arbel probably resulted from the unavailability of pollen (either for self- or crosspollination) during a considerable part of its female flowering period (Fig. 2).

The significant positive relationship observed for 'Floridian' in Kefar Hitim between yield and hybrid percentage, and between the former and proximity to 'Mauritius' (Tables 5 and 6 ), indicates an advantage for 'Floridian' to cross-pollination by 'Mauritius'. Such a relationship was not found in Arbel, apparently due to the very high percentage of hybrids produced throughout the orchard.

A well-known phenomenon in lychee is the formation of fruits with shrivelled seeds. The proportion of fruits with shrivelled seeds for 'Mauritius' and 'Floridian' was higher in the orchard where hybrid percentage was low (Tables 1, 4, and 5). Apparently, under conditions of high hybrid-fruit production, fruits with shrivelled seeds have a very low probability of survival, tending instead to abscise. The latter fruits possibly resulted from self-pollination, subsequently undergoing embryo degeneration due to inbreeding depression. This is a well-known phenomenon in many plant species (Sedgley and Griffin, 1989). In 'Mauritius', no significant difference was found in the percentage of fruits with small seeds between those produced by selfand cross-pollination (Table 2). In 'Floridian', however, the proportion of fruits with small seeds among self-pollinated fruits was over four times that in the cross-pollinated fruits (Table 2). This difference supports the assumption that seeds from selfpollinated 'Floridian' fruits tend to degenerate.

Both cultivars exhibited a significant effect of pollen parent on fruit and seed weight. Outcrossed fruits were heavier and contained heavier seeds than selfed fruits. This effect was most pronounced for seed weights in selfed 'Floridian' fruits, which is consistent with findings in other species, where seeds produced by self-pollination are smaller than those produced by cross-pollination (Craig, 1989).

The seed weight percentage of fruit is of considerable horticultural and economic importance. The results of this study show that while cross-pollination has the advantage of increasing fruit weight, this advantage is partially negated when seed weight percentage is taken into account.

Ours is the first study in which the rates of cross- vs. selfpollination in lychee orchards were determined using isozymes 
as genetic markers. It shows the usefulness of isozyme analysis as a tool for studying the pollination requirements of lychee cultivars and the effect of additional pollenizers.

\section{Literature Cited}

Bergh, B.O. 1968. Cross-pollination increases avocado set. California Citrograph. 53:97-100.

Campbell, C.W. and S.E. Malo. 1968. The Lychee. Fruit crops fact sheet 6. Florida Coop. Ext. Serv., Gainsville.

Cavaletto, C.G. 1980. Lychee, p. 469-478. In: S. Nagy and P.E. Shaw (eds.). Tropical and subtropical fruits. Avi Publ., Westport, Conn.

Chandler, W.H. 1958. Evergreen orchards, p. 252-258. 2nd (ed.). Lea and Febiger, Philadelphia.

Chapparo, J.X., R.E. Durham, G.A. Moore, and W.B. Sherman. 1987. Use of isozyme techniques to identify peach $\times$ nonpareil almond hybrids. HortScience 22:300-302.

Craig, J.L. 1989. A differential response to self-pollination: Seed size in Phornium. N.Z. J. Bot. 27:585-586.

Degani, C. and S. Gazit. 1984. Selfed and crossed proportions of avocado progenies produced by caged pairs of complementary cultivars. HortScience 19:258-260.

Degani, C., A. Goldring, and S. Gazit. 1989. Pollen parent effect on outcrossing rate in 'Hass' and 'Fuerte' avocado plots during fruit development. J. Amer. Soc. Hort. Sci. 114:106-111.

Degani, C., A. Goldring, I. Adato, R. El-Batsri, and S. Gazit. 1990. Pollen parent effect on outcrossing rate, yield, and fruit characteristics of 'Fuerte' avocado. HortScience 25:471-473.

DeGrandi-Hoffman, G., R. Hoopingarner, and R. Pulcer. 1987. REDAPOL: Pollination and fruit-set prediction model for 'Delicious' apples. Forum: Environ. Entomol. 16:309-318.

Free, J.B. and I.H. Williams. 1972. The transport of pollen on body hairs of honeybees (Apis mellifera L.) and bumblebees (Bombus spp. L.). Applied Ecol. 9:609-615.

Free, J.B. and I.H. Williams. 1976. Insect pollination of Anacardium occidental L., Mangifera indica L., Blighia sapida Koenig and Persea americana Mill. Trop. Agr. 53:125-139.

Galan-Sauco, V. and U.G. Menini. 1989. Litchi cultivation. FAO, plant production, and protection, paper 83 .

Gazit, S. and E. Gafni. 1986. Effect of hand pollination with different pollen donors on initial fruit-set in avocado. (in Hebrew, English abstr.). Israel Agresearch 1:3-17.

Goldring, A., S. Gazit, and C. Degani. 1987. Isozyme analysis of mature avocado embryos to determine outcrossing rate in a 'Hass' plot. J. Amer. Soc. Hort. Sci. 112:389-392.

Goldring, A., D. Zamir, and C. Degani. 1985. Duplicated phosphoglucose isomerase genes in avocado. Theor. Applied Genet. 71:431434

Joubert, A.J. 1986. Litchi, p. 233-246. In: S.P. Monselise (ed.).
Handbook of fruit set and development. CRC Press, Boca Raton, Fla.

Kadman, A. and E. Slor. 1982. Litchi growing in Israel (in Hebrew). Alon haNotea 36:673-688.

Kendall, D.A. and M.E. Solomon. 1973. Quantities of pollen on the bodies of insects visiting apple blossoms. J. Applied Ecol. 10:627634.

Knight, R., Jr. 1980. Origin and world importance of tropical and subtropical fruit crops, p. 1-120. In: S. Nagy and P.E. Shaw (eds.). Tropical and subtropical fruits. AVI, Westport, Conn.

Lundkvist, K. 1979. Allozyme frequency distributions in four Swedish populations of Norway spruce ( Picea abies K.). Hereditas 90:127143.

Marquard, R.D. 1988. Outcrossing rates in western pecan and the potential for increased yields. J. Amer. Soc. Hort. Sci. 105:257263.

McConchie; C.A. and D.J. Batten. 1989. Floral biology and fruit set in lychee. Proc. 2nd Natl. Lychee Seminar. 71-74.

McGregor, S.E. 1976. Insect pollination of cultivated crop plants. U.S. Dept. of Agr. Agr. Res. Ser. no. 496:247-248.

Menzel, C.M. 1984. The pattern and control of reproductive development in lychee: A review. Scientia Hort. 22:333-341.

Menzel, C.M., and D.R. Simpson. 1990. Performance and improvement of lychee cultivars: A review. Fruit Var. J. 44:197-215.

Parfitt, D.E., S. Arulsekar, and D.A. Ramming. 1985. Identification of plum $\times$ peach hybrids by isozyme analysis. HortScience 20:216218.

Popenoe, W. 1927. Manual of tropical and subtropical fruits. p. 312325. Macmillan, New York.

Scholefield, P.B. 1982. A scanning electron microscope study of flowers of avocado, litchi, macadamia and mango. Scientia Hort. 16:263272

Sedgley, M. and A.R. Griffin. 1989. Sexual reproduction of tree crops. p. 204-213. Academic Press, London.

Shaw, D.V. and R.W. Allard. 1982. Estimation of outcrossing rates in Douglas-fir using isozyme markers. Theor. Applied Genet. 62:113120

Stephenson, A.G. 1981. Flower and fruit abortion: Proximate causes and ultimate function. Annu. Rev. Ecol. System 12:253-279.

Tanksley, S.D. 1984. High rates of cross-pollination in chile pepper. HortScience 19:580-582.

Torres, A.M. and B.O. Bergh. 1978a. Isozymes as indicators of outcrossing among 'Pinkerton' seedlings. California Avocado Soc. Yearbook 62:103-110.

Torres, A.M. and B.O. Bergh. 1978b. Isozymes of 'Duke' and its derivatives. California Avocado Soc. Yearbook 62:111-117.

Vrecenar-Gadus, M. and N.C. Ellstrand. 1985. The effect of planting on outcrossing rate and yield in the 'Hass' avocado. Scientia Hort. 27:215-221 